\title{
Earthworms as indicators for different forest management types and human disturbance in Ilam oak forest, Iran
}

\author{
Mehdi Heydari ${ }^{1} \bowtie$, Hassan Poorbabaei ${ }^{2}$, Masoud Bazgir $^{1}$, Ali Salehi $^{2}$, Javad Eshaghirad $^{3}$ \\ ${ }^{1}$ University of Ilam, Faculty of Agriculture and Natural Resources, Ilam, Iran, e-mail: M_Heydari23@yahoo.com \\ ${ }^{2}$ University of Guilan, Faculty of Natural Resources, Department of Forestry, Someasara, Iran \\ ${ }^{3}$ Urmia University, Faculty of Natural Resources, Department of Forestry, Urmia, Iran
}

\section{Abstract}

There has been observed widespread destruction of natural ecosystems around the world due to population growth, land use change and clear cutting which have affected soil properties. Different management strategies have been so far implemented to reduce this crisis in various regions of the world, such as e.g. short-term and long-term conservation management in the Zagros region. However, any management approach should be evaluated with appropriate measures to determine how managed areas respond. The main objective of the present study was to evaluate the potential of earthworms as an indicator for different forest management strategies and human disturbances in Zagros oak (Quercus persica Jaub. and Spach) forest. The sites selected included undisturbed one as the control (Un), the sites under five-year conservation management (FCM) and twenty-year conservation management (TCM) as well as the disturbed site (D). The results of principal component analysis (PCA) showed that different regions separated into the components: PC1 and PC2. Un and TCM sites gathered together and represented higher values of the factors such as $\mathrm{pH}, \mathrm{K}_{\text {available }}, \mathrm{OC}$, clay content, $\mathrm{P}_{\text {available }}, \mathrm{CEC}$, overstory tree canopy, $\mathrm{N}_{\text {tot }}$, biomass and abundance of earthworms. The positive direction of the first axis reflected a gradient of EC, BD and $\mathrm{P}_{\text {tot }}$. According to the logistic model, $\mathrm{NH}_{4}-\mathrm{N}$ and EC played the most important role in earthworm presence and absence in Zagros forest ecosystem. Earthworm abundance and biomass could be a good indicator to evaluate different forest management strategies in the study area.

\section{KeY WORDS}

earthworms, management strategies, disturbance, soil, logistic model

\section{INTRODUCTION}

There is a strong relationship between human economic activities and natural resources, especially in forests and pastures in the Zagros province. Man's activities have caused different disturbances including soil erosion and clear-cut forest areas in addition to decline of soil fertility as well as species diversity and richness
(Salehi et al. 2011). In the region,, different management strategies have been implemented, such as e.g. shortterm and long-term conservation management, which affected its ecosystems in different ways (Zandebasiri et al. 2010). Soil quality is one of the prominent factors in the healthiness of different ecosystems. The knowledge on the processes ongoing in the ecosystem as well as that on soil as a vital part in the ecosystem is essential 
for finding good solutions, and therefore the properties of soil which are appropriate for evaluation of ecosystem functions should be better known and defined (Karlen et al. 2003). To study soil quality scientists have offered different indicators such as physical (Hseu et al. 1999) and chemical and biological soil properties (Doran and Parkin 1994). For monitoring soil quality indices, it is better to select soil properties that change with changing management approaches, and also show good correlation with the processes occurring in soil (Herrick 2000). Studies on soil quality with the aim to identify the effects of different management types on forests destruction are imperative (Khaledian et al. 2011). Hence, if their results point to the effects of management on soil quality, they can constitute suitable support in achieving better understanding of sustainable management (Herrick 2000; Bhardwaj et al. 2011).

Soil organisms play a vital role both in sustainable management and maintaining soil quality as they influence various properties of soil on the one hand, and on the other- are influenced by soil nature (Brady and Weil 2008). One of the most important issues for a programmer is the question how changes in soil biological communities influence soil quality (Chan and Barchia 2007). Most studies address the impacts of management strategies and destructions due to human activities on forests ecosystems through monitoring of forest plant diversity and richness (Kouamé et al. 2004), while there remain scarce knowledge about soil organisms such as earthworms. There is a wide destruction of forest ecosystems around the world owing to population growth, land use change and forest clear cutting which have strongly affected soil fertility (Dinesh et al. 2003) and soil biology (Islam and Weil 2000). Investigations show that some soil biological characteristics, such as changes in soil biological communities are measurable, in other words a study on soil microorganisms and effective processes on them can be a key indicator of soil quality in the future (Acost-Martines et al. 2007). Doran and Zeiss (2000) state that the evaluation of soil organisms as a good indicator of soil quality can be more investigable, and also less time-consuming and less costly.

Among soil organisms, earthworms are the most commonly occurring invertebrates (Tondoh et al. 2007). Earthworms enhance soil fertility and productivity through increasing availability of mineral nutrients to plants (Brady and Weil 2008) and improving the dynamics of soil organic matter (Reich et al. 2005). Abundance and activity of earthworms are influenced by soil conditions. Mboukou- Kimbasta et al. (2007) declared that soil nitrogen had a positive effect on earthworm abundance and biomass. Earthworms mineralize phosphor, nitrogen, and organic matter in manure fertilizers and turn them into nutrients available for plants (Buchanan et al. 1988). These organisms directly increase litterfall decomposition rate by enhancement of microbial activities (Tsukamoto and Sabang 2005) and advance soil physical properties by improvement of soil structure as well as water and air infiltration capability which are indispensable for plant growth (Sautter et al. 2006). The effect of land use change on density and abundance of earthworms in Hariyali area in India was examined by Bhadauria et al. (2012). The results indicated the lowest abundance of earthworms in natural forest which was severely destructed. The authors showed that conservation practices including restoration of destroyed forest improved earthworm communities and organic matter for the duration of 20 years. Tondoh et al. (2011) investigated the effects of forest destruction on earthworm population in the western part of Ivory Coast. The results showed that forest disturbance decreased soil organic carbon and soil $\mathrm{pH}$. At the same time, multi-variable regression analysis between earthworm communities and environmental variables showed that soil organic matter and $\mathrm{pH}$ were potential indicators to reflect earthworm abundance.

There are studies about changes in abundance, presence or absence and biomass of earthworms observed under destructive activities or diverse management types in different regions (Hendrix and Bonlen 2002; Aubert et al. 2003; Haynes et al. 2003; Rombke et al. 2005 ; Ammer et al. 2006). Yet, previous studies have seldom been focused on both soil physiochemical properties and earthworms under destruction and short- or long - term conservation management conditions. Regarding this topic, no comprehensive study in Zagros oak forests has been to this point carried out. The present study has been performed for the first time in Zagros oak forests located in the western part of Iran. The results of the study can offer managers and researchers novel management approaches to examine the potential of earthworms as a biological indicator for evaluation of predominating conditions in forest ecosystems. The main objective of the study was to evaluate the potential of earthworms as an indicator 
for different forest management strategies and human disturbances in the ecosystem.

\section{MATERIAL AND METHODS}

\section{Study area}

The study area is located in Zagros forests in the western part of Iran (fig. 1). In 2012, we chose four sites within 100 ha of forest area, The sites selected were divided into undisturbed one as the control (Un), the sites under five-year conservation management (FCM) and twentyyear conservation management (TCM) and the disturbed site (D). Prior to the implementation of management practices, the conditions of FCM and TCM sites were similar to those at D site. According to an aerial photograph taken in 1965 as well as communication with experts and local community, all the sites were then covered by dense forest. All the sites chosen are alike in terms of physiography (slope and altitude) and tree species structure.
The dominant tree species is oak (Quercus persica Jaub. and Spach) which covers more than $90 \%$ of the study area. Average annual precipitation and temperature are $590 \mathrm{~mm}$ and $17^{\circ} \mathrm{C}$, respectively.

\section{Soil sampling}

Soil samples were taken from 0-30 cm soil layer in May 2012, using the systematic-random sampling method $(100 \mathrm{~m} \times 200 \mathrm{~m})$. Further analyses of soil physical and chemical properties were carried out on composite samples consisting of three sub-samples taken from selected soil layer (Marañón et al. 1999). The soil samples were air dried and sieved $(2 \mathrm{~mm})$ to remove roots and coarse fragments.

\section{Analytical methods}

Soil texture was determined by the Bouyoucos hydrometer method (Bouyoucos 1927). Soil bulk density (BD) was determined by the undisturbed soil core method (Blake and Hartage 1986). Saturation percentage was

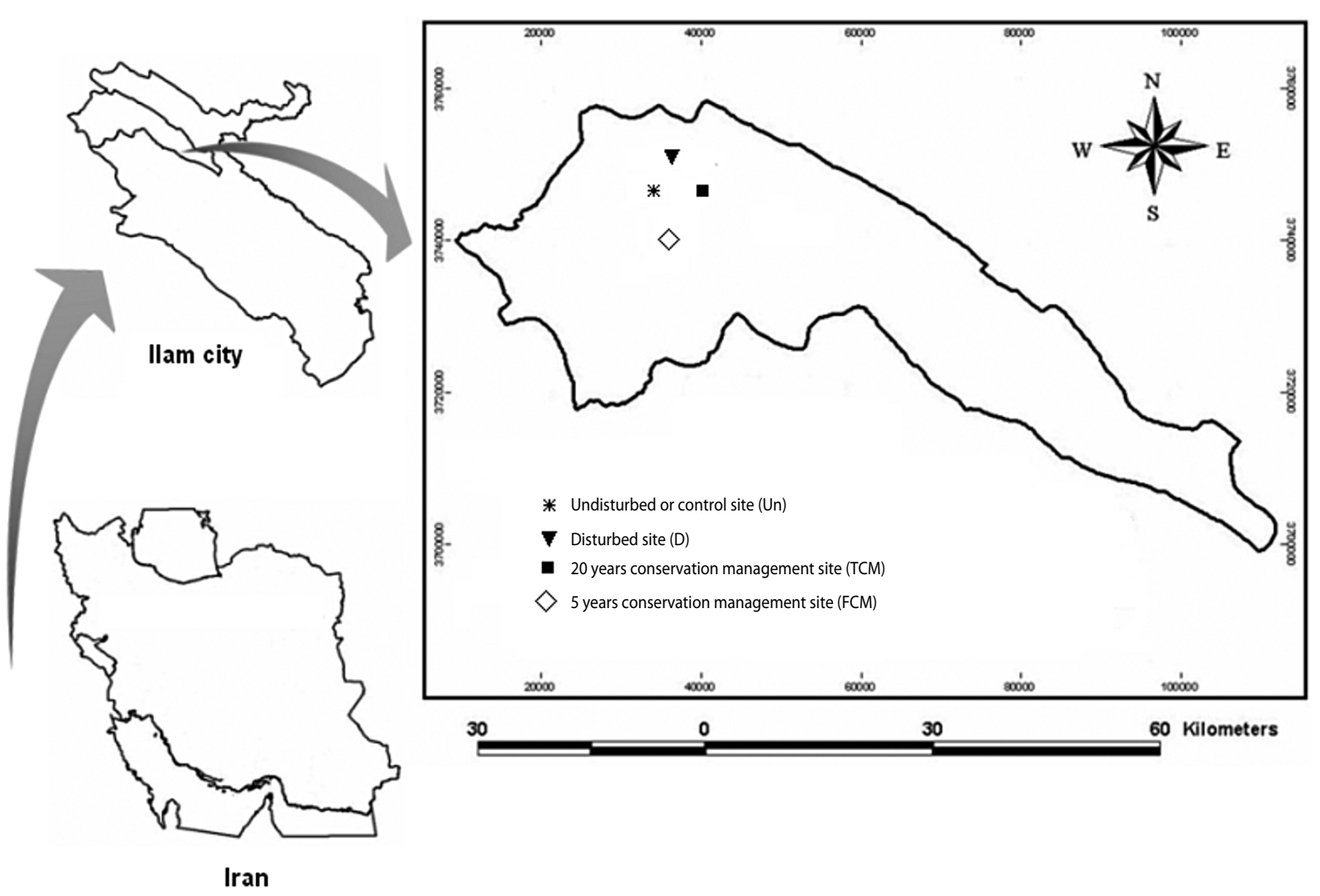

Figure 1. Location of the study sites 
determined gravimetrically (Famiglietti et al. 1998). Soil $\mathrm{pH}$ and electric conductivity (EC) were measured using a glass -electrode $\mathrm{pH}$ meter and EC meter, respectively (Kalra and Maynard 1991). Organic carbon (OC) was determined based on the Walkely and Black rapid titration method (Black 1979). Total nitrogen (N) was measured by the Kjeldah method (Bremmer and Mulvaney 1982). Flame photometry (Bastida et al. 2007) was used for measurement of total potassium. Soil cation exchange capacity (CEC) was determined based on NH4OAc extraction (Sumner and Miller 1996). Exchangeable cations $\left(\mathrm{Al}^{3+}, \mathrm{Fe}^{3+}, \mathrm{Mn}^{2+}, \mathrm{Zn}^{2+}, \mathrm{Ca}^{2+}, \mathrm{Mg}^{2+}\right.$, $\mathrm{K}^{+}, \mathrm{Na}^{+}$) were extracted using a $0.1 \mathrm{M} \mathrm{BaCl}_{2}$ (Hendershot and Duquette 1986). The extracts obtained were centrifuged, filtered (Machery-Nagel $615^{1 / 4}$ filters rinsed with $\mathrm{BaCl}_{2}$ ) and analysed by ICP-AESS (Varian, Australia). Available phosphorus was assessed by the Bray and Kurtz method (1945), soil $\mathrm{NO}_{3}-\mathrm{N}$ and $\mathrm{NH}_{4}-\mathrm{N}$ concentrations (extracted using $2 \mathrm{M} \mathrm{KCl}$ solution) were measured with a spectrophotometer (Maynard and Kalra 1993). Total $P$ was measured calorimetrically using the ascorbic acid method, followed by digestion in nitric and perchloric acid (Sommers and Nelson 1997).

\section{Earthworm sampling}

Earthworms were collected manually, around the center of each sample plot- in the lateral soil area of $50 \times 50 \mathrm{~cm}$ drilled down to the depth of $20 \mathrm{~cm}$. Earthworms were counted and then dried in the oven at $60^{\circ} \mathrm{C}$ for $24 \mathrm{~h}$. Next, dried earthworms were weighed to determine biomass (Welke, Parkinson 2003). Earthworm abundance was calculated as the number of earthworms per surface area $\left(\mathrm{m}^{2}\right)$.

\section{Statistical analyses}

The normality of data distribution and homogeneity of variances were verified by Kolmogrov-Smirnov and Levene's tests, respectively Environmental data were analyzed using one-way ANOVA and in line with homogeneity of variance, significant differences between means were determined by Duncan's test. Consistent with data normality we used Pearson's correlation to analyze the relation between earthworm densities (No/ $\mathrm{m}^{2}$ ) and biomass and environmental variables. In order to determine the most effective factors with influence on plot distribution, multivariate procedure such as principal component analysis (PCA) was used (Arekhi et al. 2010). PCA was used in order to trim down many variables to a smaller group of newly derived variables (components) that adequately summarized initial information. These variables were independent of each other, and for that reason could be used as predictors in PCA. PCA is the ordination technique that constructs a theoretical variable that minimizes the total residual sum of squares after fitting straight lines to species data. Data standardization was necessary to use PCA because the variables were measured in different units. Therefore, data were centered and standardized by the standard deviation (Jalilvand and Kooch 2012). Logistic regression was used to investigate the relationship between earthworm presence and absence and environmental factors. Also, the power and efficiency of the logistic regression model was evaluated based on the omnibus test. Two statistics coefficient of determination's Pseudo (Cox and Snell R Square and Nagelkerke R Square) were used to examine the explanatory power of independent variables in expression of a dependent variable (Habibpoor and Safri, 2012). The coefficient of determination's Pseudo is between 0 and 1 . If the value of this statistic is closer to 1 , it means that independent variables have a greater role in explanation of variance in a dependent variable. In addition, the Hosmer-Lemeshow test was used to determine fitness of the logistic model. To run the model, the following equation was used:

$$
\begin{aligned}
\log \text { it }(Y) & =\text { natural } \log (\text { odds })=\ln \frac{P}{1-P}= \\
& =a+\beta_{1} X_{1}+\beta_{2} X_{2}+\beta_{k} X_{k}
\end{aligned}
$$

where:

$P$ - the probability of an event with the presence of an independent variable $X$,

$a$ - the constant or parameters related to the coordinate axes,

$\beta$ - the regression coefficient and $X$ represents independent or predictive variables.

Simple linear regression was used to predict the value of a dependent variable $(y)$ (here the most important soil attributes in the presence or absence of earthworms, based on logistic regression) derived from the value of an independent variable $(x)$ (here biomass or abundance of earthworms) based on the following equation:

$$
y=a+b x
$$


where:

$y$ - a dependent variable,

$a$ - the intercept,

$b$ - a slope,

$x-$ an independent variable.

The statistical analyses were carried out using PCORD, V. 4.17 package (McCune and Mefford 1999) and SPSS, version 16 .

\section{Results}

\section{Principal component analysis (PCA)}

To distinct the most effective variables on the distribution of sample plots, PCA was performed for 17 variables in 200 plots. The results of PCA ordination are presented in tab. 1 and fig. 2. Broken-stick eigenvalues for the data set indicated that the first two principal components (PC1 and PC2) clearly captured more variance. The first two principal components together accounted for $63 \%$ of the total variance in the data set. Therefore, $54.38 \%$ and $8.64 \%$ variances were accounted for the first and second principal components, respectively (tab. 2). The first principal component was by far the most important for representing variation in this study.

Table 1. Pearson's correlation coefficient of environmental variables and $\mathrm{PC} 1$ and $\mathrm{PC} 2$

\begin{tabular}{|l|c|c|}
\hline \multicolumn{1}{|c|}{ Variables } & AXIS 1 & AXIS 2 \\
\hline \multicolumn{1}{|c|}{1} & 2 & 3 \\
\hline $\mathrm{pH}$ & $-0.6^{* *}$ & $0.236 \mathrm{~ns}$ \\
\hline $\mathrm{EC} / \mathrm{dS} \mathrm{m}^{-1}$ & $0.868^{* *}$ & $0.13 \mathrm{~ns}$ \\
\hline $\mathrm{P}_{\text {ava }} / \mathrm{mg} \mathrm{kg}^{-1}$ & $-0.898^{* *}$ & $0.147 \mathrm{~ns}$ \\
\hline $\mathrm{K}_{\text {ava }} / \mathrm{mg} \mathrm{kg}^{-1}$ & $-0.696^{* *}$ & $0.07 \mathrm{~ns}$ \\
\hline$\% / \mathrm{Clay}$ & $-0.887^{* *}$ & $0.105 \mathrm{~ns}$ \\
\hline$\% / \mathrm{Silt}$ & $0.168 \mathrm{~ns}$ & $-0.711^{* *}$ \\
\hline$\% / \mathrm{Sand}$ & $0.278 \mathrm{~ns}$ & $0.155 \mathrm{~ns}$ \\
\hline $\mathrm{BD} / \mathrm{g} \mathrm{cm}^{-3}$ & $0.773^{* *}$ & $0.444^{*}$ \\
\hline$\% / \mathrm{OC}^{*}$ & $-0.903^{* *}$ & $0.167 \mathrm{~ns}$ \\
\hline$\% / \mathrm{N}_{\text {tot }}$ & $-0.922^{* *}$ & $0.171 \mathrm{~ns}$ \\
\hline $\mathrm{P}_{\text {tot }} / \mathrm{mg} \mathrm{kg}^{-1}$ & $0.852^{* *}$ & $0.246 \mathrm{~ns}$ \\
\hline $\mathrm{K}_{\text {tot }} / \mathrm{mg} \mathrm{kg}^{-1}$ & $-0.304^{*}$ & $-0.462^{*}$ \\
\hline $\mathrm{NO} 3-\mathrm{N} / \mathrm{mg} \mathrm{kg}^{-1}$ & $-0.07 \mathrm{~ns}$ & $-0.832^{* *}$ \\
\hline $\mathrm{NH} 4-\mathrm{N} / \mathrm{mg} \mathrm{kg}^{-1}$ & $-0.931^{* *}$ & $0.130 \mathrm{~ns}$ \\
\hline
\end{tabular}

\begin{tabular}{|l|l|l|}
\hline \multicolumn{1}{|c|}{1} & \multicolumn{1}{c|}{2} & 3 \\
\hline $\mathrm{CEC} / \mathrm{cmol}(+) \mathrm{kg}^{-1}$ & $-0.818^{* *}$ & $0.139 \mathrm{~ns}$ \\
\hline Overstory tree canopy $\%$ & $-0.5^{*}$ & $-0.09 \mathrm{~ns}$ \\
\hline Earthworms $/ \mathrm{No} \mathrm{m}^{2}$ & $-0.551^{*}$ & $-0.23 \mathrm{~ns}$ \\
\hline Earth worm biomass gr $/ \mathrm{m}^{2}$ & $-0.652^{* *}$ & $-0.229 \mathrm{~ns}$ \\
\hline
\end{tabular}

${ }^{*}$ Significant $(P<0.05),{ }^{* *}$ Significant $(P<0.01)$, ns: No significant $(\mathrm{n}=50)$.

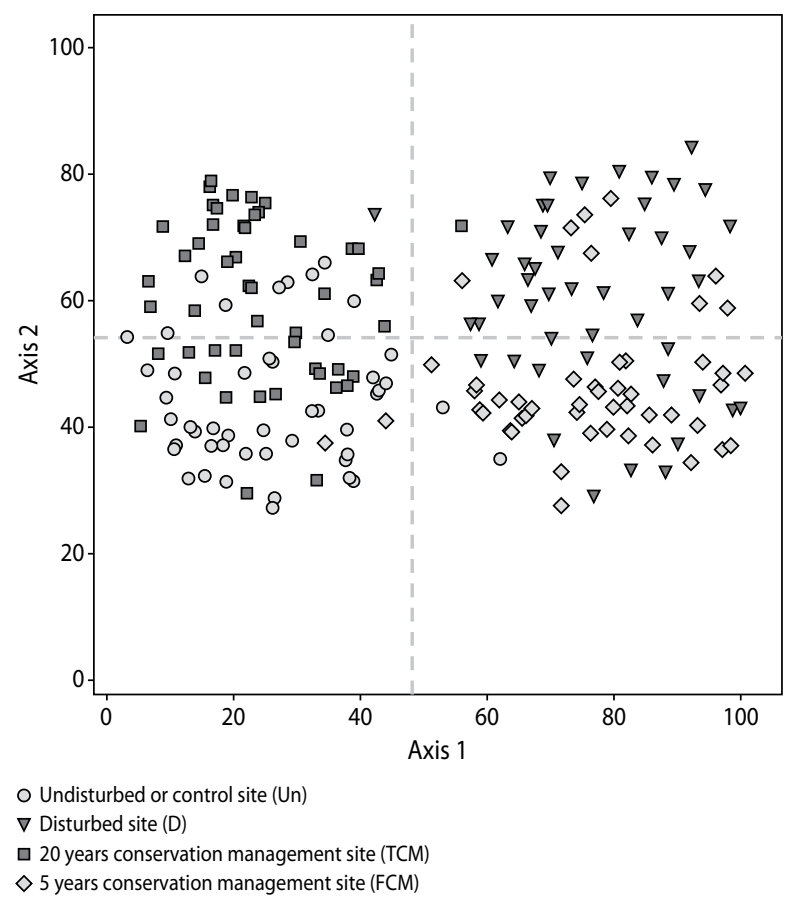

Figure 2. PCA ordination diagram for sample plots of different sites

The results show that negative direction of the first axis represents the factors such as $\mathrm{pH}, \mathrm{K}_{\text {available, OC, Clay, }}$ Pavailable, CEC, overstory tree canopy, $\mathrm{N}_{\text {tot }}$, as well as earthworm abundance and biomass. In other words, these factors showed a strong correlation with PC1 negative direction. Un and TCM sites were strongly correlated with the negative direction of the first axis and were gathered together. This means that environmental factors in Un and TCM sites were similar. The positive direction of the first axis reflected a gradient of EC, BD and $\mathrm{P}_{\text {tot. }}$. The sample plots in FCM and D sites gathered together around this axis (fig. 2). As mentioned above, Un and TCM sites indicated higher earthworm density. Earthworms showed a positive response to increased environmental factors in these sites. 
Table 2. Eigenvalue, variance percentage, cumulative percentage of variance and broken-stick eigenvalue from 1 to 10 axes PCA axes

\begin{tabular}{|c|c|c|c|c|}
\hline $\begin{array}{c}\text { Axes } \\
\text { No }\end{array}$ & $\begin{array}{c}\text { Eigen- } \\
\text { value }\end{array}$ & $\begin{array}{c}\text { Variance } \\
\text { percentage }\end{array}$ & $\begin{array}{c}\text { Cumulative } \\
\text { percentage } \\
\text { of variance }\end{array}$ & $\begin{array}{c}\text { Broken-stick } \\
\text { Eigenvalue }\end{array}$ \\
\hline 1 & 11.965 & 54.385 & 54.385 & 3.691 \\
\hline 2 & 1.902 & 8.645 & 63.030 & 2.691 \\
\hline 3 & 1.563 & 7.107 & 70.137 & 2.191 \\
\hline 4 & 1.078 & 4.900 & 75.037 & 1.857 \\
\hline 5 & 0.964 & 4.383 & 79.420 & 1.607 \\
\hline 6 & 0.755 & 3.430 & 82.850 & 1.407 \\
\hline 7 & 0.675 & 3.070 & 85.919 & 1.241 \\
\hline 8 & 0.467 & 2.122 & 88.041 & 1.098 \\
\hline 9 & 0.430 & 1.956 & 89.997 & 0.973 \\
\hline 10 & 0.358 & 1.629 & 91.626 & 0.862 \\
\hline
\end{tabular}

\section{Logistic regression model}

The results showed that the presence and absence of earthworms can be explained with high probability (73\%) by independent variables including soil physical and chemical properties and overstory tree canopy. Between the variables entered into regression analysis, $\mathrm{OC}, \mathrm{N}_{\text {tot }}, \mathrm{NH}_{4}-\mathrm{N}, \mathrm{NO}_{3}-\mathrm{N}, \mathrm{CEC}, \mathrm{BD}, \mathrm{EC}$ and overstory tree canopy were able to predict variation of a dependent variable, i.e. the presence -absence of earthworms. The evaluation of the power and efficiency of the logistic regression model based on the omnibus test showed that the model was acceptable and significant $(\mathrm{P}<0.01)$. Two statistics coefficient of determination's Pseudo, Cox and Snell $\mathrm{R}^{2}$ and Nagelkerke $\mathrm{R}^{2}$ were as high as 0.73 and 0.78 , respectively, and this showed that independent variables had important role in explaining variance of earthworm presence and absence of. In fact, these variables explained 73.22 and $78.6 \%$ percentage the variations of the presence and absence of earthworms.

\section{Hosmer-Lemeshow test for goodness of fit}

Based on the Hosmer-Lemeshow test, fitting prediction variations of a dependent variable was significant. In other words, the research model had good fitness and independent variables were able to predict high proportion of a dependent variable (earthworms).
The results showed that the variables entered into the model: $\mathrm{NH}_{4}-\mathrm{N}, \mathrm{NO}_{3}-\mathrm{N}, \mathrm{pH}, \mathrm{CEC}, \mathrm{OC}$ and $\mathrm{K}_{\text {avail- }}$ able had a positive effect on the probability of the presence of earthworms. Exp (B) is the exponentiated B coefficient. When $\operatorname{Exp}(\mathrm{B})>1$, it means that with increasing values of an independent variable, the presence of earthworms is more probable. BD and EC had a negative effect on the probability of the presence of earthworms. In other words, with decreasing $\mathrm{BD}$ and EC values, the possibility of earthworm presence increased. B is the logistic regression coefficient that is significant (+ or - ) and shows the effects of each independent variable on a dependent variable. The Wald statistic provides a significance test for each predictor. If the statistic was significant for a variable, this variable was entered into the model (tab. 3).

Table 3. Logistic model for earthworm presence and absence, exponentiated coefficients or Exp (B),significance level (sig), Wald chi-square test (Wald) and logistic regression coefficient (B)

\begin{tabular}{|l|c|c|c|c|}
\hline \multicolumn{1}{|c|}{ Variables } & $\operatorname{Exp}(\mathrm{B})$ & Sig & Wald & B \\
\hline $\mathrm{EC} / \mathrm{dS} \mathrm{m}^{-1}$ & 0.37 & 0.03 & 3.11 & $1.7-$ \\
\hline $\mathrm{BD} / \mathrm{g} \mathrm{cm}^{-3}$ & 0.23 & 0.01 & 5.9 & $0.34-$ \\
\hline $\mathrm{pH}$ & 1.13 & 0.04 & 0.8 & 0.14 \\
\hline$\% / \mathrm{OC}$ & 1.14 & 0.03 & $4 / 2$ & 1.15 \\
\hline $\mathrm{P}_{\text {ava }} / \mathrm{mg} \mathrm{kg}^{-1}$ & 1.17 & 0.02 & 4.2 & 1.12 \\
\hline $\mathrm{K}_{\text {ava }} / \mathrm{mg} \mathrm{kg}^{-1}$ & 1.23 & 0.03 & 2 & 3.5 \\
\hline $\mathrm{NO} 3-\mathrm{N} / \mathrm{mg} \mathrm{kg}^{-1}$ & 1.33 & 0.40 & 6 & 3.2 \\
\hline $\mathrm{NH} 4-\mathrm{N} / \mathrm{mg} \mathrm{kg}^{-1}$ & 1.45 & 0.01 & 6.1 & 6.18 \\
\hline $\mathrm{CEC} / \mathrm{cmol}^{-}+\mathrm{kg}^{-1}$ & 1.17 & 0.03 & 4.7 & 2.3 \\
\hline
\end{tabular}

The logistic model for earthworm presence-absence in this study was explained by the following equation:

$$
\begin{gathered}
\mathrm{P}(\text { earthworm presence and absence })= \\
=8.5+6.18 \mathrm{NH}_{4}-\mathrm{N}+3.2 \mathrm{NO}_{3}-\mathrm{N}+3.5 \mathrm{~K}_{\mathrm{ava}}+1.12 \mathrm{P}_{\mathrm{ava}}+ \\
+1.15 \mathrm{OC}+0.14 \mathrm{pH}+2.3 \mathrm{CEC}-1.7 \mathrm{EC}-0.34 \mathrm{BD}
\end{gathered}
$$

Based on the above model, increased $\mathrm{NH}_{4}-\mathrm{N}$, $\mathrm{NO}_{3}-\mathrm{N}, \mathrm{K}_{\text {available }}, \mathrm{P}_{\text {available }}, \mathrm{OC}, \mathrm{pH}$ and $\mathrm{CEC}$ had a positive effect on the presence of earthworms whereas increased EC and BD had a negative effect on the presence and absence of earthworms. 


\begin{tabular}{|c|c|c|}
\hline 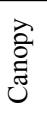 & $\begin{array}{l}n \\
\stackrel{y}{0} \\
\stackrel{1}{0} \\
0\end{array}$ & $\begin{array}{l}0 \\
\vdots \\
0 \\
0 \\
0\end{array}$ \\
\hline ن & 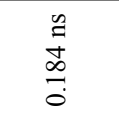 & $\stackrel{*}{m}$ \\
\hline $\begin{array}{l}z_{1} \\
0^{m} \\
z\end{array}$ & 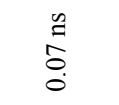 & 華 \\
\hline 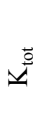 & 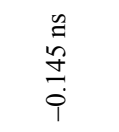 & 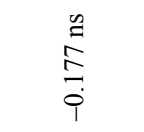 \\
\hline$\Omega^{\bar{a}}$ & 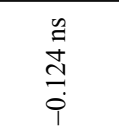 & $\begin{array}{l}n \\
\stackrel{n}{n} \\
\stackrel{n}{0}\end{array}$ \\
\hline $\begin{array}{l}z_{1} \\
1 \\
\text { zín } \\
z\end{array}$ & 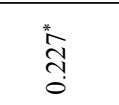 & 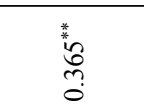 \\
\hline$z^{\frac{0}{a}}$ & \begin{tabular}{l}
$* 0$ \\
\multirow{1}{*}{} \\
$\vdots$ \\
0
\end{tabular} & ले \\
\hline 用 & 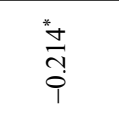 & $\begin{array}{l}\text { *. } \\
\text { 官 } \\
0 \\
0 \\
0\end{array}$ \\
\hline $\begin{array}{l}\overrightarrow{\tilde{E}} \\
\text { Dू }\end{array}$ & $\begin{array}{c}n \\
\stackrel{m}{m} \\
\stackrel{m}{9} \\
\ddot{i}\end{array}$ & $\begin{array}{c}\tilde{a} \\
\infty \\
= \\
\\
\end{array}$ \\
\hline$\frac{\vec{\omega}}{\dot{\omega}}$ & 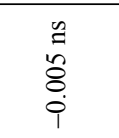 & \begin{tabular}{l}
\multicolumn{2}{c}{} \\
0 \\
0 \\
0 \\
0
\end{tabular} \\
\hline 胥 & \begin{tabular}{l}
$*$ \\
\multirow{2}{*}{} \\
\multirow{2}{0}{} \\
0 \\
0
\end{tabular} & 菜 \\
\hline 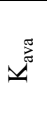 & $\begin{array}{l}n \\
\stackrel{n}{0} \\
\stackrel{0}{0}\end{array}$ & तี \\
\hline 2 & $\begin{array}{l}\frac{n}{5} \\
\stackrel{5}{0} \\
0\end{array}$ & $\stackrel{*}{\stackrel{*}{2}}$ \\
\hline 8 & $\begin{array}{l}\mathscr{y} \\
\stackrel{1}{0} \\
0\end{array}$ & 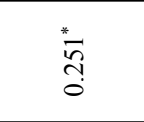 \\
\hline ن. & $\underset{\text { * }}{\stackrel{*}{+}}$ & 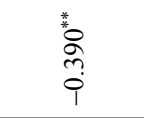 \\
\hline$\frac{\mathrm{I}}{2}$ & $\frac{*}{0}$ & ⿳亠丷⿵冂丶 \\
\hline 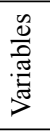 & 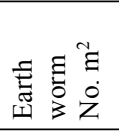 & 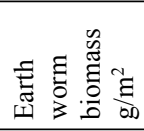 \\
\hline
\end{tabular}

\section{Correlation between the abundance and biomass of earthworms and environmental factors}

According to Pearson's correlation earthworm abundance positively correlated with $\mathrm{pH}$, clay contents, $\mathrm{N}_{\text {tot }}, \mathrm{NH}_{4}-\mathrm{N}$, while $\mathrm{EC}$ and $\mathrm{BD}$ showed a negative correlation with earthworm abundance.. Furthermore, earthworm biomass showed a positive correlation with $\mathrm{pH}, \mathrm{OC}, \mathrm{P}_{\text {available }}, \mathrm{K}_{\text {available, clay }}$ contents, $\mathrm{N}_{\text {tot }}, \mathrm{NH}+4$ and CEC, while it correlated negatively with EC and $\mathrm{BD}$ (tab. 4). These results corresponded with the logistic model.

One-Way ANOVA showed that all the factors examined in this study significantly differed among the study areas. Duncan's test showed that $\mathrm{pH}$, $\mathrm{NH}_{4}-\mathrm{N}, \mathrm{N}_{\text {tot }}$, CEC, OC, clay contents, canopy percentage and biomass of earthworms were the highest in Un and TCM sites and the lowest - in D and FCM sites (tab. 5 and fig. 3).
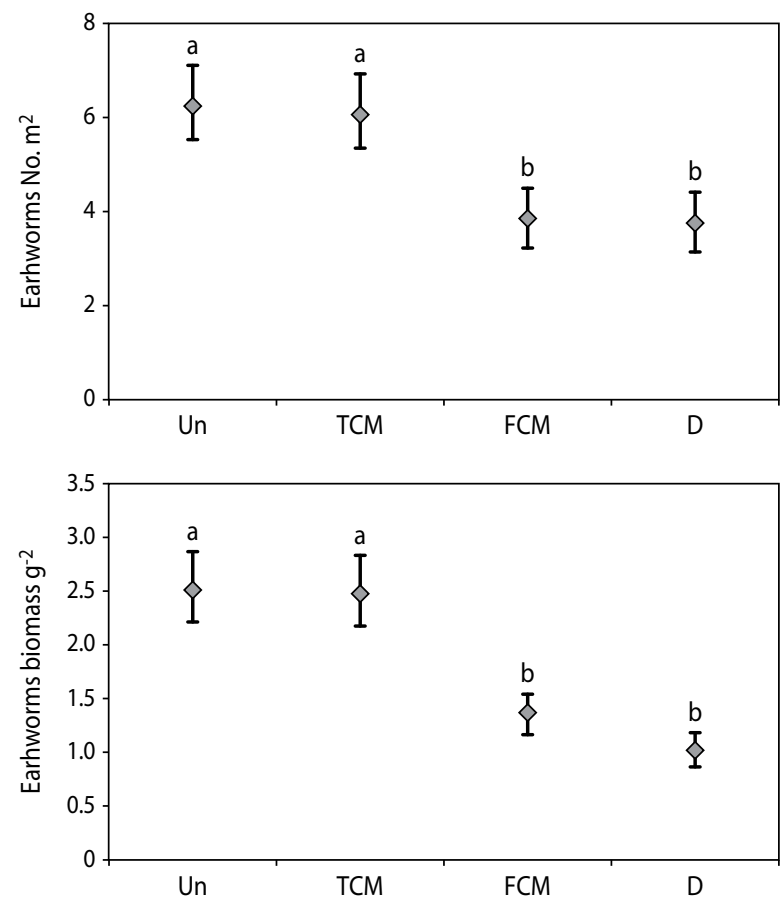

Figure 3. Abundance and biomass of earthworms in four sites with different conditions

Un - control; FCM - five-year conservation management; TCM - twenty-year conservation management; $\mathrm{D}$ - disturbed site.

The values represent mean \pm standard error $(n=50)$, different lowercase letters indicate significant differences $(\mathrm{P}<0.01)$.

According to the logistic model, $\mathrm{NH}_{4}-\mathrm{N}$ and $\mathrm{EC}$ had the most important role in the presence and absence of earthworms. Therefore, linear regression between abundance and biomass of earthworms and these two important factors had shown in fig. 4. There was observed a strong positive correlation between earthworm abundance and biomass and $\mathrm{NH}_{4}-\mathrm{N}$. This means the two variables (earthworm abundance and biomass and $\mathrm{NH}_{4}-\mathrm{N}$ ) varied in 
Table 5. Soil characteristics, earthworm abundance and biomass and overstory tree canopy in four sites with different conditions

\begin{tabular}{|c|c|c|c|c|c|}
\hline \multicolumn{6}{|c|}{ Sites } \\
\hline Variables & Un & TCM & FCM & $\mathrm{D}$ & Sig \\
\hline $\mathrm{pH}$ & $7.46( \pm 0.01) \mathrm{a}$ & $7.32( \pm 0.07) b$ & $7.21( \pm 0.01) \mathrm{c}$ & $7.25( \pm 0.01) \mathrm{c}$ & $0.02^{*}$ \\
\hline $\mathrm{EC} / \mathrm{dS} \mathrm{m}^{-1}$ & $0.34( \pm 0.01) \mathrm{c}$ & $0.38( \pm 0.02) \mathrm{c}$ & $0.67( \pm 0.01) b$ & $0.88( \pm 0.01) \mathrm{a}$ & $0.04^{*}$ \\
\hline$\% / \mathrm{OC}$ & $4( \pm 0.14) \mathrm{a}$ & $2.9( \pm 0.03) b$ & $1.33( \pm 0.02) \mathrm{c}$ & $1.23( \pm 0.06) \mathrm{c}$ & $0.001^{* *}$ \\
\hline $\mathrm{P}_{\mathrm{ava}} / \mathrm{mg} \mathrm{kg}^{-1}$ & $22.76( \pm 0.5) b$ & $26.71( \pm 0.5) \mathrm{a}$ & $8.6( \pm 0.39) \mathrm{c}$ & $8.23( \pm 0.35) \mathrm{c}$ & $0.001^{* *}$ \\
\hline $\mathrm{K}_{\mathrm{ava}} / \mathrm{mg} \mathrm{kg}^{-1}$ & $621.26( \pm 9) \mathrm{a}$ & $488.16( \pm 8.8) b$ & $425.77( \pm 1.97) \mathrm{c}$ & $421.7( \pm 5) \mathrm{c}$ & $0.000^{* *}$ \\
\hline$\% /$ Clay & $36.48( \pm 0.57) \mathrm{a}$ & $38.7( \pm 0.4) \mathrm{a}$ & $21.95( \pm 0.67) b$ & $20.22( \pm 0.8) b$ & $0.002^{* *}$ \\
\hline$\% /$ Silt & $34.7( \pm 0.52) b$ & $35.1( \pm 0.54) b$ & $41.54( \pm 0.8) \mathrm{a}$ & $34.48( \pm 0.87) b$ & $0.02^{*}$ \\
\hline$\% /$ Sand & $28.74( \pm 0.73) \mathrm{c}$ & $26.14( \pm 0.4) \mathrm{c}$ & $34.71( \pm 1) b$ & $45.28( \pm 0.8) \mathrm{a}$ & $0.000^{* *}$ \\
\hline $\mathrm{BD} / \mathrm{g} \mathrm{cm}^{-3}$ & $1.18( \pm 0.01) \mathrm{d}$ & $1.26( \pm 0.008) \mathrm{c}$ & $1.31( \pm 0.009) b$ & $1.59( \pm 0.009) \mathrm{a}$ & $0.01^{*}$ \\
\hline$\% / \mathrm{N}_{\text {tot }}$ & $0.59( \pm 0.01) \mathrm{a}$ & $0.307( \pm 0.006) b$ & $0.12( \pm 0.002) \mathrm{c}$ & $0.14( \pm 0.007) \mathrm{c}$ & $0.001^{* *}$ \\
\hline $\mathrm{P}_{\mathrm{tot}} / \mathrm{mg} \mathrm{kg}^{-1}$ & $549.95( \pm 5.7) \mathrm{d}$ & $610.38( \pm 7.3) \mathrm{c}$ & $697.38( \pm 9.7) b$ & $880.47( \pm 6.3) \mathrm{a}$ & $0.000^{* *}$ \\
\hline $\mathrm{K}_{\mathrm{tot}} / \mathrm{mg} \mathrm{kg}^{-1}$ & $3362.23( \pm 31.29) b$ & $3221.93( \pm 39) \mathrm{c}$ & $3602.93( \pm 18) \mathrm{a}$ & $3375.75( \pm 36) \mathrm{a}$ & $0.001^{*}$ \\
\hline NO3-N/mg kg-1 & $22.72( \pm 0.36) b$ & $29.86( \pm 0.43) \mathrm{a}$ & $20.91( \pm 0.39) \mathrm{c}$ & $15.48( \pm 0.36) \mathrm{d}$ & $0.002^{* *}$ \\
\hline NH4-N/mg kg-1 & $0.64( \pm 0.01) \mathrm{a}$ & $0.66( \pm 0.008) \mathrm{a}$ & $0.180 .018 \mathrm{~b}$ & $0.15( \pm 0.003) b$ & $0.01^{*}$ \\
\hline $\mathrm{CEC} / \mathrm{cmol}^{(+)} \mathrm{kg}^{-1}$ & $2.24( \pm 0.03) \mathrm{a}$ & $1.88( \pm 0.03) b$ & $1.43( \pm 0.01) \mathrm{c}$ & $1.45( \pm 0.01) \mathrm{c}$ & $0.002^{* *}$ \\
\hline Earthworms/No $\mathrm{m}^{2}$ & $6.3( \pm 0.84) \mathrm{a}$ & $6.1( \pm 0.8) \mathrm{a}$ & $4( \pm 0.6) b$ & $3.84( \pm 0.5) b$ & $0.02^{*}$ \\
\hline $\begin{array}{l}\text { Earthworms } \\
\text { biomass } \mathrm{g} \mathrm{m}^{-2}\end{array}$ & $2.54( \pm 0.35) \mathrm{a}$ & $2.48( \pm 0.35) \mathrm{a}$ & $1.42( \pm 0.22) b$ & $0.99( \pm 0.14) b$ & $0.000^{* *}$ \\
\hline $\begin{array}{l}\text { Overstory tree } \\
\text { canopy/\% }\end{array}$ & $40( \pm 3.32) \mathrm{a}$ & $35( \pm 2.97) \mathrm{a}$ & $25( \pm 2) b$ & $15( \pm 1.5) \mathrm{c}$ & $0.000^{* *}$ \\
\hline
\end{tabular}

Values are mean \pm standard error $(\mathrm{n}=50)$; different lowercase letters represent difference significant $(P<0.05) ;{ }^{*}$ significant $(\alpha=5 \%){ }^{* *}$ significant $(\alpha=1 \%)$ according to Duncan test.

the same direction $\left(\mathrm{R}^{2}=0.641\right.$ and 0.608 respectively) (fig. 4A, 4B). At the same time, there was found a strong negative correlation between earthworm abundance and biomass and EC. A negative correlation means that two variables (here, EC and earthworm abundance and biomass) vary in opposite directions (fig. 4C, 4D). In other words, we can say that $\mathrm{EC}$ and $\mathrm{NH}_{4}-\mathrm{N}$ values can be predictable based on earthworm abundance and biomass.

\section{Discussion}

Studies on soil quality and suitable indices expand with broadening human knowledge about soil as an essential agent in biosphere, which is essential not only for food production, but also for preservation of natural environment, at a local, regional, and global level (Glantz 1995). Taking into consideration a key role of earthworms in organic matter cycling and improving the soil structure in numerous ecosystems, the recognition of elements which control earthworm abundance is definitely necessary for soil sustainable management (Fonte et al. 2009).

\section{Physical and chemical properties of soil and canopy percentage in relation to management and destruction}

The results of this study showed that environmental factors in the control site (Un) and those under twentyyear conservation management site (TCM) are considerably similar. In Un and TCM sites, the values of soil 
A

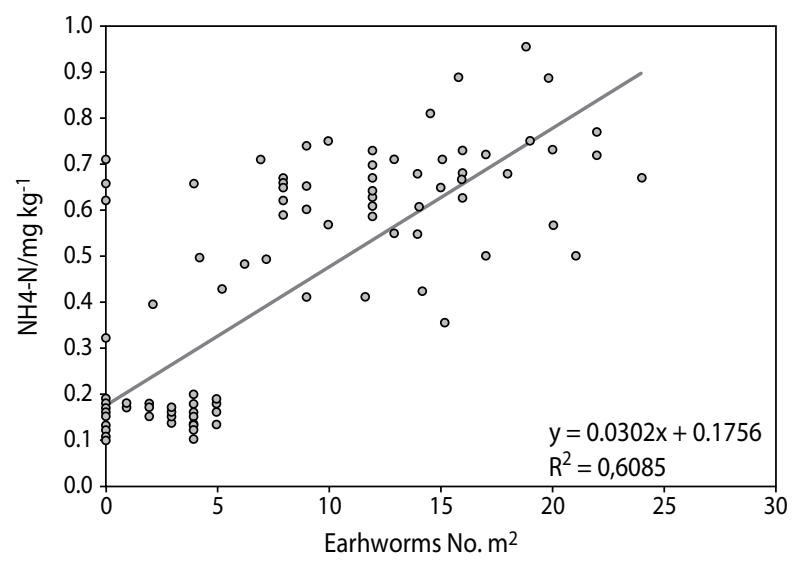

C

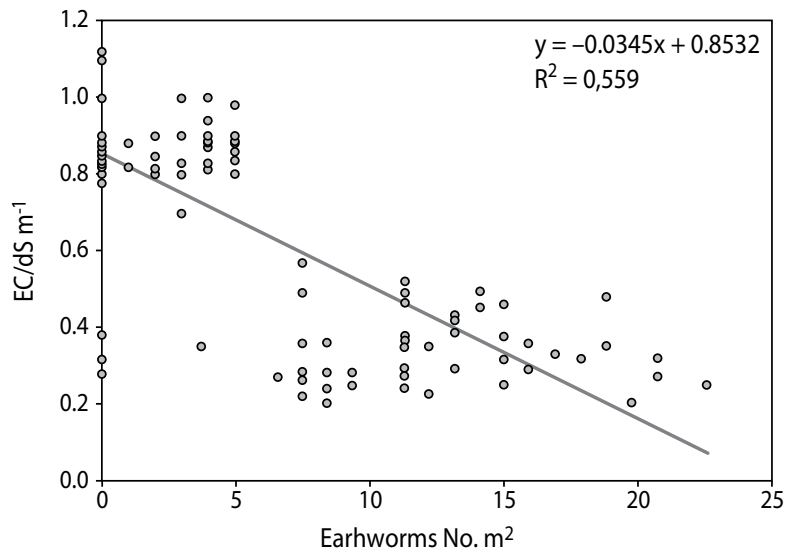

B

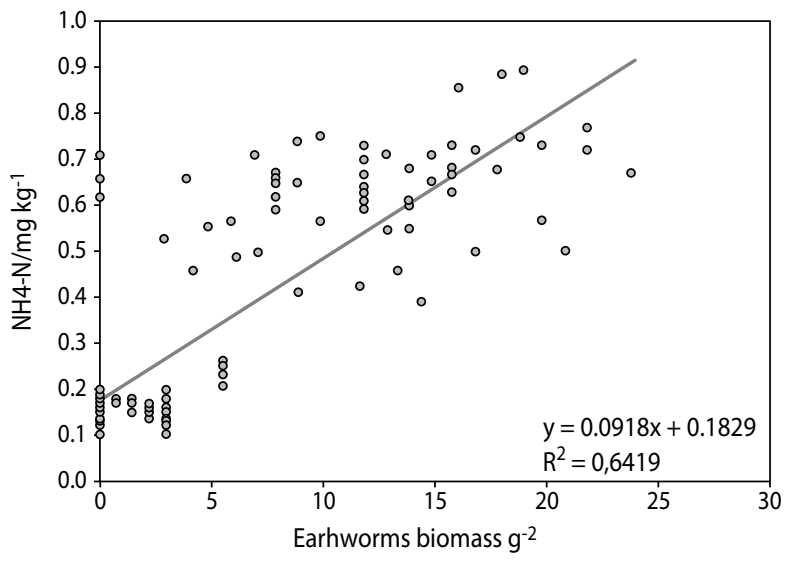

D

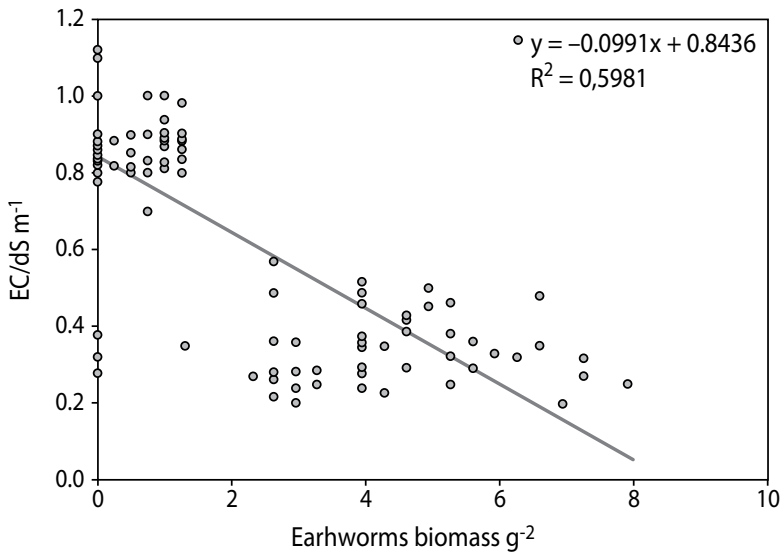

Figure 4. Linear regression between earthworm abundance and biomass and $\mathrm{EC}$ and $\mathrm{NH}_{4}-\mathrm{N}$ in the study sites

$\mathrm{pH}, \mathrm{CEC}, \mathrm{K}_{\text {available }}$ and $\mathrm{P}_{\text {available, clay contents, } \mathrm{OC} \text {, total }}$ and mineral nitrogen, foliar litterfall percentage and canopy percentage were higher than in five-year conservation management site (FCM) as well as in not managed or highly disturbed (D) sites. On the other hand, in FCM and D sites, soil EC, BD and $\mathrm{P}_{\text {tot }}$ were higher than in Un and TCM sites. Consistent with the results, the destructive factors such as overgrazing, understory agriculture and so on in FCM and D sites had more effects on soil physical and chemical properties. Besides, edaphic conditions in FCM site, even though it is designated for this conservation practice, are not classified as suitable. Long-term conservation management positively influenced physical and chemical properties of soil, so that environmental conditions in TCM were similar to those in Un site. Studies have proved that destruction affected soil properties, which resulted in forest frag- mentation, and finally changed vegetation and soil nutrient contents in forest (Kelemen et al. 2012). The canopy of trees and shrubs in FCM and D sites was almost half of that in Un and TCM sites. This can be one of the main factors affecting soil quality in the areas studied. One study showed that the canopy of blue oak (Quercus douglasii Hook. and Arn.) significantly increased soil fertility (Dahlgren et al. 2003). In contrast, clear cutting decreased soil nutrient and organic matter content and also had a negative effect on soil nutrient cycling (Dahlgren et al. 2003). Soil organic matter is the main source of nutrients and soil fertility, and plays an important role in advancing soil physico-chemical and biological properties (Brady and Weil 2008). Studies have showed positive effects of conservation management on soil properties (Shaoshan et al. 2008). Shaoshan et al (2008) studied the effects of deforestation on soil quality in the 
Ziwuling region located in northwestern Shaanxi province (China) and showed that with increasing destruction, there drastically changed soil physico-chemical properties, and particularly - organic matter contents. In this study, high bulk density observed in D site can be related to low organic matter content (Ahmad et al. 2007) and soil compaction (Dauda and Samari 2002). In Un and TCM sites, high clay percentage in soil essentially influenced an increase in nutrient contents and CEC. High CEC values found in Un and TCM sites, were not unexpected, because both clay and organic matter contents (Rashidi and Seilsepour 2008), which both have been in these regions higher than in two sites of (D) and (FCM). Generally, our results showedthat the two conservation management types (FCM and TCM) and destruction obviously influenced soil physical and chemical properties in Zagros forest ecosystem.

\section{Abundance and biomass of earthworms in relation to soil properties}

It was found the positive effect of conservation management on biomass and presence of earthworms. Earthworm abundance and biomass in Un and TCM sites were almost two times higher than in two destructed sites (D and FCM). The study on Irish pastures proved that an increase of earthworm abundance was connected with a longer period of conservation management, which resulted from augmenting earthworm community by adding plant debris into soil (Curry et al. 2008). Our results signify the negative effect of destruction related to soil properties on abundance, biomass and presence of earthworms., Other study indicated that alteration and destruction of forests impacted soil physico-chemical properties, followed by a decrease of earthworm density and abundance (Bhadauria et al. 2012). The results showed a strong positive relationship between earthworm abundance and biomass and $\mathrm{N}_{\text {tot }}$, NH4-N, OC, $\mathrm{P}_{\text {available }}$, $\mathrm{K}_{\text {available, clay contents and CEC. }}$ On the other hand, there was a negative correlation observed between earthworm abundance and biomass and $\mathrm{EC}$ and BD. In fact, the suitable condition of soil in Un and TCM increased abundance and biomass of earthworms. Boyer et al. (1991) found a positive correlation between earthworm abundance and soil fertility. Kooch et al. (2010) studied the effect of canopy opening in beech forest on soil chemical and biological properties and found higher earthworm abundance and biomass in the areas with closed canopy, which indicated high values of soil $\mathrm{C} / \mathrm{N}$ ratio and CEC. Mboukou-Kimbatsa et al. (2007) declared that soil $\mathrm{N}$ positively affected abundance and biomass of earthworms. On the other hand, canopy opening in D site, above and beyond its negative effects on different soil properties and consequentially - on earthworms population, could directly reduce earthworm abundance by bringing about an increase of soil temperature (Nachtergale et al. 2002). According to the results of this study, there is a positive correlation between earthworm abundance and biomass with clay percentage in soil and also according to PCA high clay percentage, abundance and biomass of earthworms in two sites of (Un) and (TCM) have been approved. In a study on earthworms in southern Australian fields, there was asserted a negative correlation between earthworm population and sand percentage in soil (Buckerfield et al. 1997). In addition, Fonte et al. (2009), when investigating earthworm population in relation to soil organic matter dynamics and management in California cropping systems showed a strong positive correlation between earthworm abundance and soil clay percentage On the other hand, no correlation between earthworm abundance and silt and sand, was shown, which corresponds with our results.

\section{Presence and absence of earthworms in relation to soil properties}

According to the logistic model in this study, the presence and absence of earthworms can be a proper indicator of changes in soil physico-chemical characteristics. Soil salinity mostly results in the reduction of growth, community sizes and macro and microorganism activity in soil (Owojori et al. 2009). This is due to the fact that soil salinity directly affects nutrition (Nemati et al. 2011). Studies showed that earthworms can be an indicator of salinity stress in soils (Owojori and Reinecke 2009). High contents of nutrient elements in Un and TCM sites and earthworm high abundance showed that earthworms can be a suitable indicator for soil fertility in Zagros forest ecosystem. Earthworms' existence is related to accessible organic matter in soil (Poier and Richter 1992). Nurhidayati (2011) investigated the effects of long-term forest management on earthworm diversity and density. The results showed that with $25 \%$ increase of organic carbon, density and biomass of earthworms increased up to $64 \%$ and $83 \%$, respectively. 
Furthermore, with an increase of soil total $\mathrm{N}$ to $25 \%$ , density and biomass of earthworms increased up to $79 \%$ and $75 \%$, respectively. Curry (1998) stated that soil $\mathrm{pH}$ reduction is an effective factor in decline of earthworm communities. Soil $\mathrm{pH}$ and soil physicochemical properties affect the numbers and variety of soil organisms, and these factors are influenced by human activities such as land degradation (Brady and Weil 2008). Soil aeration and oxygen supply are necessary for soil organisms to transform organic $\mathrm{N}$ to mineral N (NH4-N and NO3-N) (Brady and Weil 2008). Earthworms prefer habitats with proper aeration and their activities in soil lead to formation of horizontal and vertical tunnels, which improve soil aeration. In fact, earthworms are important as organisms which interact with microorganisms and influence primary production, decomposition and nitrogen cycling (Nadiri et al. 2011). In the present study, both the logistic model and PCA proved that there was a good relationship between earthworm community and soil aeration, $\mathrm{OC}$ as well as mineral $\mathrm{N}\left(\mathrm{NH}_{4}-\mathrm{N}\right.$ and $\left.\mathrm{NO}_{3}-\mathrm{N}\right)$. When compared to other sites studied, soil structure and BD in Un and TCM were more suitable, which can be related to high abundance of earthworms in these sites. The change of soil structure into granular shape is due to earthworms, who also crush plant debris, change its positioning and push forward organic matter parts enhancing formation of aggregates so that it can be considerably influences organic matter dynamics and soil chemical properties (Ladd et al. 1993). Based on multiple regression analysis, Tondoh et al. (2007) found that OC and soil $\mathrm{pH}$ were potential criteria for changes in earthworm abundance. Earthworms respond to soil degradation - equally to soil physical and chemical changes (Linden et al. 1994). Analyses of soil quality factors showed that long-term planting of tea and destruction of site caused a decrease of organic matter, N, P, K, porosity, soil acidity, and an increase of BD and soil compaction. Earthworm abundance as a biological index declined significantly due to long-term planting of tea (Van dang 2007).

Along with the results of this research, it can be stated that human activities caused forest destruction and changes in physical and chemical properties of soil in the Zagros region. Abundance and presence and absence of earthworms could be a suitable indicator for forest management. Hence, earthworms as such indictor can be used to monitor susceptible sites as Zagros, eas- ily and less time-consuming. Based on the results of the present study, it can be declared that unlike other soil characteristics, suchlike salinity and acidity (quality indices of the forest site according to other studies), earthworms as a part of soil phone deliver more various physical and chemical properties simultaneously, and they might be a proper index in diagnosing soil quality in Ilam oak forest.

\section{Conclusion}

Management approaches should be evaluated with appropriate measures to determine how a given area responds to management. In the present study, we evaluated the potential of earthworms as an indicator for different forest management types and human disturbances in Zagros oak (Quercus persica Jaub. and Spach) forests. The study area had different soil attributes due to disturbance and short- and long-term conservation management. Even with conservation management carried out in subsequent 5 years, FCM site demonstrated no desirable conditions. In contrast, after 20 years of conservation management, TCM site conditions were analogous to those observed in Un site. According to our results, earthworm, biomass and abundance showed high sensitivity to BD and EC increase. Our study showed that earthworm abundance and biomass could be a good indicator to evaluate different management types in forest sites with different conditions.

\section{Acknowledgements}

This research was financially supported by University of Guilan, Iran. We are also indebted to Mostafa Adibnejad, an expert at Ilam Natural Resources office, for help in field works. We thank all our friends in Ilam Natural Recourses office.

\section{References}

Acosta-Martínez V., Cruz L., Sotomayor-Ramírez D., Pérez-Alegría L. 2007. Enzyme activities as affected by soil properties and land use in a tropical watershed. Applied Soil Ecology, 35, 35-45. 
Ahmad N., Ul-Hassan F., Qadir G. 2007. Effect of Subsurface Soil Compaction and Improvement Measures on Soil Properties. International Journal of Agriculture and Biology, 9, 509-513.

Ammer S., Weber K., Abs C., Ammer C., Prietzel J. 2006. Factors influencing the distribution and abundance of earthworm Communities in pure and converted scots pine stands. Applied Soil Ecology, 33, 10-21.

Arekhi S., Heydari M., Pourbabaei H. 2010. VegetationEnvironmental Relationships and Ecological Species Groups of the Ilam Oak Forest Landscape, Iran. Caspian Journal of Environment Science, 8, $115-125$.

Aubert M., Hedde M., Decaens T., Bureau F., Margerie P., Alard D. 2003. Effects of tree canopy composition on earthworms and other macro-invertebrates in beech forests of upper Normandy (France). $\mathrm{Pe}$ dobiologia, 47, 904-912.

Bastida F., Moreno J.L., Hernández T., García C., 2007. The long-term effects of the management of a forest soil on its carbon content, microbial biomass and activity under a semi-arid climate. Applied Soil Ecology, 37, 53-62.

Bhadauria T., Kumar P., Kumar R., Maikhuri R.K., Rao K.S., Saxena K.G. 2012. Earthworm populations in a traditional village landscape in Central Himalaya, India. Applied Soil Ecology, 53, 83-93.

Bhardwaj A.K., Jasrotia P., Hamilton S.K., Robertson G.P. 2011. Ecological management of intensively cropped agro-ecosystems improves soil quality with sustained productivity. Agriculture, Ecosystems and Environment, 140, 419-429.

Black C.A. 1979. Methods of soil analysis. American Society of Agronomy, 2, 771-1572.

Blake G.R., Hartage K.H. 1986. Bulk Density. In: Methods of Soil Analysis (ed.: A. Klute), Agronomy Monograph, Madison, 363-367.

Bouyoucos G.J. 1927. The hydrometer as a new method for the mechanical analysis of soils. Soil Sicience, 23, 343-353.

Boyer J., Micellon R., Chabanne A., Reversat G., Tiber R. 1991. Effect of terfoli cover crop and earthworm inoculation on maize crop and soil organisms in Reunion Island. Biology and Fertility of Soils, 2, 364-370.

Brady N., Weil R. 2008. The Nature and Properties of Soils. Pearson Perntice Hall, New Jersey.
Bray R.H., Kurtz L.T. 1945. Determination of total organic and available forms of phosphorus in soils. Soil Science, 59, 39-45.

Bremmer J.M., Mulvaney C.S. 1982. Nitrogen total. In: Methods of soil analysis. Part 2. Chemical and microbiological properties 9 (eds.: A.L. Page et al.), American Society of Agronomy, Inc., Madison, 595-624.

Buchanan M.A., Russel E., Block S.D. 1988. Chemical Characterization and Nitrogen Mineralisation Potentials of Vermicompost Derived from Differing Organic Wastes. In: Earthworm in Waste and Environmental Management (eds.: C.A. Edward and E.F. Neuhauser), SPB Academic Publishing, The Hague, The Netherlands, 231-240.

Buckerfield J.C., Lee K.E., Davoren C.W., Hannay J.N. 1997. Earthworms as indicators of sustainable production in dryland cropping in southern Australia. Soil Biology and Biochemistry, 29, 547-554.

Chan K.Y., Barchia I. 2007. Soil compaction controls the abundance, biomass and distribution of earthworms in a single dairy farm in south-eastern Australia. Soil and Tillage Research, 94, 75-82.

Curry J.P. 1998. Factors affecting earthworm abundance in soils. In: Earthworm Ecology (ed.: C.A. Edwards), Lucie Press, Boca Raton, 37-64.

Curry J.P., Doherty P., Purvis G., Schmidt O. 2008. Relationships between earthworm populations and management intensity in cattle-grazed pastures in Ireland. Applied Soil Ecology, 39, 58-64.

Dahlgren R.A., Horwath W.R., Tate K.W., Camping T.J. 2003. Blue oak enhance soil quality in California oak woodlands. California Agriculture, 57, 42-47.

Dauda A., Samari A. 2002. Cowpea yield response to soil compaction under tractor traffic on a sandy loam soil in the semi-arid region of northern Nigeria. Soil and Tillage Research, 68, 17-22.

Dinesh R., Ghoshal Chaudhuri S., Ganeshamurthy A.N., Dey C. 2003. Changes in soil microbial indices and their relationships following deforestation and cultivation in wet tropical forests. Applied Soil Ecology, 24, 17-26.

Doran J.W., Parkin T.B. 1994. Defining and assessing soil quality. In: Defining Soil Quality for a Sustainable Environment (eds.: J.W. Doran, D.C. Coleman, D.F. Bezdick, B.A. Stewart), Soil Science Society of America, Special Publication, No. 35, 3-21. 
Doran J.W., Zeiss M.R. 2000. Soil health and sustainability: managing the biotic component of soil quality. Applied Soil Ecology, 15, 3-11.

Famiglietti J., Rudnicki J., Rodell M. 1998. Variability in surface moisture content along a hillslope transect. Journal of Hydrology, 210, 259- 281.

Fonte S.J., Winsome T., Six J. 2009. Earthworm populations in relation to soil organic matter dynamics and management in California tomato cropping systems. Applied Soil Ecology, 41, 206-214.

Glanz J.T. 1995. Saving Our Soil: Solutions for Sustaining Earth's Vital Resource. Johnson Books, Boulder, CO.

Habibpoor K., Safri R. 2012. A comprehensive guide to using the SPSS. Loya publication, Tehran.

Haynes R.J., Dominy C.S., Graham M.H. 2003. Effect of agricultural land use on soil organic matter status and the composition of earthworm communities in Kwazulu-natal, South Africa. Agriculture, Ecosystems and Environment Journal, 95, 453-464.

Hendershot W.H., Duquette M. 1986. A simple bariumchloride method for determining cation-exchange capacity and exchangeable cations. Soil Science, 50, 605-608.

Hendrix P.F., Bonlen P.G. 2002. Exotic Earthworm invasions in North America: Ecological and policy implications. Bioscience, 9, 1-11.

Herrick J.E. 2000. Soil quality: an indicator of sustainable land management? Applied Soil Ecology, 15, 75-83.

Hseu Z.Y., Chen Z.S., Wu Z.D. 1999. Characterization of placic horizons in two subalpine forest Inceptisols. Soil Science Society of America Journal, 63, 941-947.

Islam K.R., Weil R.R. 2000. Land use effects on soil quality in a tropical forest ecosystem of Bangladesh. Agriculture, Ecosystems and Environment, 79, 9-16.

Jalilvand H., Kooch Y. 2012. Factors influence the distribution and abundance of earthworm communities in difference forest types man - made and natural forests. International Journal of Green and Herbal Chemistry, 1, 26-38.

Kalra Y.P., Maynard D.G. 1991. Methods manual for forest soil and plant analysis. Canadian Forest Service, Alberta.

Karlen D.L., Ditzler C.A., Andrews S.S. 2003. Soil quality: why and how? Geoderma, 114, 145-156.
Kelemen K., Mihók B., Gálhidy L., Standovár T. 2012. Dynamic response of herbaceous vegetation to gap opening in a Central European beech stand. Silva Fennica, 46, 53-65.

Khaledian Y., Kiani F., Ebrahimi F., Movahedi Naeini A. 2011. Impact of forest degradation, changing land use and building villas on some indicators of soil quality in the watershed, Golestan province. Journal of Water and Soil Conservation, 18, 167-184.

Kooch Y., Hosseini S.M., Mohammadi J., Hojjati S.M. 2010. The Effects of Gap Disturbance on Soil Chemical and Biochemical Properties in a Mixed Beech - Hornbeam Forest of Iran. Ecologia Balkanika, 2, 39-56.

Kouamé F.N., Bongers F., Poorter L., Traoré D. 2004. Climbers and logging in the Forêt Classée du HautSassandra, Côte-d'Ivoire. Forest Ecology and Management, 194, 259-268.

Ladd J.N., Foster R.C., Skjemstad J.O. 1993. Soil structure: carbon and nitrogen metabolism. Geoderma, $56,401-434$.

Linden D.R., Hendrix F.P., Colemen D.C., Vliet P.C.J. 1994. Fauna indicators of soil quality. In: Defining soil quality for a sustainable environment (eds.: J.W. Doran, D.C. Coleman, D.F. Bezdicek, B.A. Stewart), SSSA Special Publication, 35, 91-103.

McCune B., Mefford M.J. 1999. PC-ORD. Multivariate Analysis of Ecological Data, Version 4. MjM Software Design, Gleneden Beach, Oregon, USA.

Marañón T., Ajbilou R., Ojeda F., Arroyo J. 1999. Biodiversity of woody species in oak woodlands of southern Spain and northern Morocco. Forest Ecology and Management, 115, 147-156.

Maynard D.G., Kalra Y.P. 1993. Nitrate and exchangeable ammonium nitrogen. In: Soil Sampling and Methods of Analysis (ed.: M.R. Carter), Lewis Publishers, Boca Raton, FL, USA, 25-38.

Mboukou-Kimbatsa I., Bernhard-Reversat F., Loumeto J.J., Ngao J., Lavelle P. 2007. Understory vegetation, soil structure and soil invertebrates in Congolese eucalypt plantations, with special reference to the invasive plant Chromolaena odorata and earthworm populations. European Journal of Soil Biology, 43, 48-56.

Nachtergale L., Ghekiere K., De Schrijver A., Muys B., Luyssaert S., Lust N. 2002. Earthworm biomass 
and species diversity in windthrow sites of a temperate lowland forest. Pedobiologia, 46, 440-451.

Nadiri S., Omrani G.A., Makki Ale Agha M., Emtyazjoo M. 2011. Determination of Biochemical Changes in Cow Manure During the Process of Vermicopost with the Usage of Earthearthworm (Eisenia Fetida). Advances in Environmental Biology, 5, 3624-3628.

Nemati F., Raiesi F., Hosseinpur A.R. 2011. The Study of Populations and Growth Characteristics of Earthworms (Lumbricus terrestris L.) in a Soil Salinized with $\mathrm{NaCl}$ and the Importance of Organic Amendments in Alleviating Salinity Effects. Journal of Water and Soil, 24, 1097-1108.

Nurhidayati, Arisoesilaningsih E., Suprayogo D., Hairiah K. 2011. Long-Term Impact of Conventional Soil Management to Earthworm Diversity and Density On Sugarcane Plantation in East Java, Indonesia. Journal of Nature Studies, 10, 16-25.

Owojori O.J., Reinecke A.J. 2009. Avoidance behaviour of two eco-physiologically different earthworms (Eisenia fetida and Aporrectodea caliginosa) in natural and artificial saline soils. Chemosphere, 75, 279-283.

Owojori O.J., Reinecke A.J., Rozanov A.B. 2009. The combined stress effects of salinity and copper on the earthworm Eisenia fetida. Applied Soil Ecology, 41, 277-285.

Poier K.R., Richter J. 1992. Spatial distribution of earthworms and soil properties in an arable loess soil. Soil Biology and Biochemistry, 24, 1601-1608.

Rashidi M., Seilsepour M. 2008. Modeling of soil cation exchange capacity based on Soil organic carbon. Journal of Agricultural and Biological Science, 3, 41-45.

Reich P.B., Oleksyn J., Modrzynski, J., Mrozinski P., Hobbie S.E., Eissenstat D.M., Chorover J., Chadwick O.A., Hale C.M., Tjoelker M.G. 2005. Linking litter calcium, earthearthworm and soil properties: A common garden test with 14 tree species. Ecology Letters, 8, 811-818.

Rombke J.S., Diden W. 2005. The use of earthworms in ecological soil classification and assessment concepts. Forest Ecology and Management, 41, 42-53.

Salehi A., Mohammadi A., Safari A. 2011. Investigation and comparison of physical and chemical soil properties and quantitative characteristics of trees in less-damaged and damaged area of Zagross forests (Case study: Poldokhtar, Lorestan province). Iranian Journal of Forest, 3, 81-89.

Sautter K.D., Brown C.G., James S.W., Pasini D.H., Nunesand N., Benito P. 2006. Present knowledge on earthworm biodiversity in the state of Parana, Brazil. European Journal of Soil Biology, 42, 296-300.

Shaoshan A., Zheng F., Zhang F., Pelt V., Hamer V., Makeschin F. 2008. Soil quality degradation processes along a deforestation chronosequence in the Ziwuling area, China. Catena, 75, 248-256.

Sommers L.E., Nelson D.W. 1997. Determination of total phosphorus in soils: A rapid percholoric acid digestion procedure. Soil Science Society of America, Proceedings 36, 902-904.

Sumner M.E., Miller W.P. 1996. Cation exchange capacity and exchange coefficients. In: Methods of soil analysis. Part 3. Chemical methods (ed.: D.L. Sparks), Soil Science Society of America. Book Series 5, Madison, Wis., 1202-1229.

Tondoh J., Monin L., Tiho S., Csuzdi C. 2007. Can earthworms be used as bio-indicators of land-use perturbations in semi-deciduous forest. Biology and Fertility of Soils, 43, 585-592.

Tondoh J.E., Guei A.M., Csuzdi C., Okoth P. 2011. Effect of land-use on the earthworm assemblages insemi-deciduous forests of Central-West Ivory Coast. Biodiversity and Conservation, 20, 169-184.

Tsukamoto J., Sabang J. 2005. Soil macro-fauna in an Acacia mangium plantation in comparison to that in a primary mixed dipterocarp forest in the lowlands of Sarawak, Malaysia. Pedobiologia, 49, 69-80.

Van Dang M. 2007. Quantitative and qualitative soil quality assessments oftea enterprises in Northern Vietnam. African Journal of Agricultural Research, 2, 455-462.

Welke S.E., Parkinson D. 2003. Effect of Aporrectodea trapezoides activity on seedling, growth of Pseudotsuga menziesii nutrient dynamics and microbial activity in different forest soils. Journal of Forest Ecology and Management, 173, 169-186.

Zandebasiri M., Ghazanfari M., Sepahvand H., Fatehi P. 2010. Presentation of decision making pattern for forest management unit under uncertainty conditions (Case study: Taf local area-Lorestan). Iranian Journal of Forest, 3, 109-120. 